\title{
Uncertainty and Risk in Mainstream Economics: An Outline
}

\author{
Tomasz Zalega*
}

\begin{abstract}
Undoubtedly, risk and uncertainty are not the fundamental economic categories, yet they play an important role in economic sciences and economic practice. Unfortunately, economists do not agree as to which term was used first and offer their different interpretations. The notions "risk" and "uncertainty" often occur together and are even treated as synonyms but they do not mean the same. The article presents selected concepts and classifications of these two terms. Considerations on risk and uncertainty should focus on improving and multiplying risk measurement methods and developing theories of taking decisions that make actions more rational. All economic sciences, economic men (households, businesses), and thus the entire economy, are expecting new ways to reduce negative consequences of uncertainty and risk and increase benefits associated with these states.

This article aims to outline the phenomena of uncertainty and risk. The first part focuses on clarifying the two terms and discussing their basic types. The next section concentrates on the differences between uncertainty and risk, followed by risk measurement methods and evaluation criteria for decisions made under uncertainty. The main part hereof covers decisionmaking under risk. This issue is presented by providing some insight into the principle of expected value maximisation, the St. Petersburg paradox, the expected utility hypothesis, the principle of subjective expected utility, the Allais paradox, the prospect theory and the concept of experimental utility.
\end{abstract}

Keywords: decision-making, risk, uncertainty.

Submitted: 15.04.2016 | Accepted: 06.09.2016

\section{Niepewność i ryzyko w ekonomii głównego nurtu - zarys problematyki}

Niewatpliwie ryzyko i niepewność nie należa do fundamentalnych kategorii ekonomicznych, a mimo to odgrywaja ważna role $w$ naukach ekonomicznych i praktyce gospodarczej. Niestety, ekonomiści nie sa zgodni co do pierwszeństwa ich użycia i proponuja odmienne ich interpretacje. Określenia „ryzyko” i „niepewnośc” często występuja razem bądz sa ze soba nawet utożsamiane, ale nie oznaczaja tego samego. W artykule przedstawiono wybrane pojęcia i klasyfikacje terminów „ryzyko” i „niepewnośc”.

Rozważania dotyczace kwestii zwiazanych z ryzykiem i niepewnościa powinny sie koncentrować na doskonaleniu i pomnażaniu metod pomiaru ryzyka oraz rozwijaniu teorii podejmowania decyzji zwiększających racjonalizację dziatań. Na nowe sposoby ograniczania negatywnych konsekwencji niepewności i ryzyka oraz zwiększania korzyści towarzyszacych

\footnotetext{
Tomasz Zalega - Professor at the University of Warsaw, National Economy Department, Faculty of Management, University of Warsaw.

Mailing address: National Economy Department, Faculty of Management, University of Warsaw, Szturmowa St. 1/3, 02-678 Warszawa; e-mail: tomasz.zalega@wp.pl.
} Ministry of Science
and Higher Education Republic of Poland
The creation of the English-language version of these publications is financed in the framework of contract No. 768/P-DUN/2016 by the Ministry of Science and Higher Education committed to activities aimed at the promotion of education. 
tym stanom oczekuja wszystkie nauki ekonomiczne, podmioty gospodarujące (gospodarstwa domowe, przedsiębiorstwa) $i$ w efekcie cata gospodarka.

Celem artykutu jest zarysowanie istoty zjawisk niepewności i ryzyka. W pierwszej części opracowania skoncentrowano się na wyjaśnieniu obu terminów i omówieniu ich podstawowych rodzajów. W dalszej części tekstu uwaga została skupiona na różnicach między niepewnościa a ryzykiem, a następnie na metodach pomiaru ryzyka oraz kryteriach oceny decyzji $w$ warunkach niepewności. Zasadnicza czesść artykutu została poświęcona podejmowaniu decyzji w warunkach ryzyka. Zagadnienie to zostało naświetlone przez przybliżenie czytelnikowi zasady maksymalizacji oczekiwanej wartości, paradoksu petersburskiego, teorii oczekiwanej użyteczności, zasady subiektywnie oczekiwanej użyteczności, paradoksu Allais'a, teorii perspektyw oraz koncepcji użyteczności doświadczalnej.

Słowa kluczowe: podejmowanie decyzji, ryzyko, niepewność.

Nadesłany: 15.04.2016 | Zaakceptowany do druku: 06.09.2016

JEL: L26, 032

\section{Introduction}

Uncertainty and risk are not fundamental economic categories, yet they play an important role in economic sciences. This is because every decision is to a certain degree accompanied by uncertainty and risk, depending on time and situation. In the decision theory, a significant part is played by claims on rational decisionmaking according to which economic men (consumers, businesses) are driven by the principle of maximum gain. This principle is related to the expected utility maximisation and was forged by Nicholas Bernoulli in the $18^{\text {th }}$ century. Since the 1940 s, scientists, on the basis of numerous experiments, have repeatedly formulated the principles governing the expected utility hypothesis. Many studies and experiments carried out by them have clearly shown that people often violate the axioms of rational decision-making. Those studies have resulted in the establishment of, inter alia, paradoxes of rationality, i.e. inconsistencies between theory and reality.

This article aims to outline the phenomena of uncertainty and risk. The first part focuses on clarifying the two terms and discussing their basic types. The next section concentrates on the differences between uncertainty and risk, followed by risk measurement methods and evaluation criteria for decisions made under uncertainty. The main part hereof covers decision-making under risk. This issue is presented by providing some insight into the principle of expected value maximisation, the St. Petersburg paradox, the expected utility hypothesis, the principle of subjective expected utility, the Allais paradox, the prospect theory and the concept of experimental utility. Finally, major conclusions end this study.

\section{The Concept and Types of Uncertainty}

We encounter many uncertainties in the economic life. This is because uncertainty forms part of the surrounding reality. Consumers are faced with the uncertainty of their income and employment as well as the threat of losses that may ensue from natural disasters. Companies are uncertain about their costs, and their incomes are also burdened with uncertainty as to the prices and volume of production.

Uncertainty as a phenomenon was first referred to by Plato in Phaedo, where he considered uncertainty as to the fate of souls in the afterlife. A similar issue was raised by Arnobius of Sicca and in much later works by Blaise Pascal, a French philosopher, physicist and mathematician.

The concept of uncertainty as the antonym of certainty (that is lack of doubt) is understood in many various ways. Praktyczny stownik wspótczesnej polszczyzny (Practical Dictionary of Contemporary Polish) defines uncertainty as a lack of selfconfidence, insecurity, lack of information about the future course of events and inability to predict the consequences of the choices made and actions taken; anxiety when awaiting resolutions, decisions, etc. 
(Praktyczny stownik wspótczesnej polszczyzny, 2002, p. 456). Hence, uncertainty is an inestimable possibility of achieving a particular result. Uncertainty is most commonly expressed through terms such as: possible, necessary, probable, conceivable and believable. The term "probable" has long been used in theoretical and practical considerations related to statistical experiments. In turn, the notions "possible", "necessary", "conceivable" and "believable" are used in pairs, highlighting their duality, for instance if an event is necessary, the opposite event is not possible. To determine how "probable" or "possible" something is, uncertainty is often graded, e.g. more probable, a little probable, etc. This means that the notion of uncertainty involves gradation of compatibility between information and reality. Information can also be imprecise, meaning that there are no clear boundaries of value sets to which a variable within the information considered should belong. Uncertainty is a condition in which the future possible alternatives and the chances of their occurrence are not known. Uncertainty is often equated with risk that is present in all areas of human activity when people are not able to control or accurately predict the future. The concept of uncertainty may thus be said to involve randomness and is most often used as a synonym of unreliability of and doubt as to something or someone.

This notion is relatively clear from the intuitive viewpoint. It denotes ignorance about certain events. We usually express our knowledge about the world as statements, i.e. declarative sentences. If such statements can only be true or false, no uncertainty exists. Such a situation is the main object of study of classical logic.

Uncertainty usually refers to individual, unique or random phenomena. It can be interpreted by means of the opposite concept, namely certainty, which denotes predicting the results of actions taken without any doubt whatsoever. S. Heilpern defines uncertainty as a phenomenon concerning situations of no information or ignorance about or inability to determine the probability distribution. Under the classical approach, uncertainty covers the risk of the very narrowly understood uncertainty and ignorance (Heilpern, 2001, p. 18). As defined by R. Wiśniewski, uncertainty encompasses all factors and phenomena that result from identification, technical (data collection), calculation and interpretation difficulties and other problems that may be considered major (Wiśniewski, 2007). An equally interesting definition was suggested by W. Grzybowski, who recognised uncertainty as a decision-making situation where the decision-maker does not know all decision-making parameters and thus the possibility of achieving the set objective of action (Grzybowski, 1995, p. 34). In this context, uncertainty means an information situation where knowledge is missing about not only conditions but also results of an action being taken and hence their distribution in a possible set of alternative actions.

Uncertainty may be caused by a lack of information, an unknown degree of inaccuracy of the available information, a lack of technical possibilities to obtain the necessary information, a failure to undertake important measurements and other reasons. Uncertainty may, therefore, be said to manifest itself in a multitude of forms. This, in turn, makes it necessary to identify various criteria in order to understand the nature of uncertainty. The type that is most often distinguished is probabilistic uncertainty which can be determined based on a known probability distribution. Its opposite is stochastic uncertainty with an unknown probability distribution function, where this distribution can, however, be derived based on a sample. Another kind of uncertainty is strategic uncertainty for which the set of permissible values is only known.

Given that we do not know what will happen in the future and our knowledge is not complete, the usefulness of our statements about the future will vary depending on the case. With this in mind, two categories of uncertainty may be distinguished in the related literature (van der Heijden, 2000, p. 95):

1. structural - when we consider the possibility of an event that is so unique that does not give us any indication as to its probability. The possibility of occurrence of an event is presented by means of a causal chain of reasoning, yet we have no evidence to assess how likely this event could be.

2. unknown - when we cannot even imagine the event. With hindsight, we feel that such events were numerous and we 
must assume that this will hold true in the future. Nonetheless, we have no clue suggesting what kind of events these might be.

The degree of uncertainty depends on two groups of factors beyond the control of the decision-maker, namely external conditions and scope and time horizon of decisions being taken. Uncertainty associated with external conditions increases as:

- operating conditions become more complex and interdependent,

- operating conditions change more rapidly,

- the variability of operating conditions becomes harder to predict,

- the effects of decisions become more dependent on external conditions,

- the decision-maker's control over external conditions weakens.

Uncertainty is also associated with the nature of the decision being made and increases when (Williams, Smith, Young, 2002, pp. 29-31):

- the time horizon for decision implementation is extended

- the time horizon for the effects of choices being made is extended,

- the scope of consequences of those choices widens.

\section{The Concept of Risk: Semantics and Typology}

The concept of risk ${ }^{1}$ is most commonly associated with tempting fate, a lack of certainty as to the successful completion of actions undertaken. Hence, risk is estimable probability of achieving results This term is widely used in business, trade, insurance theory and decision-making.

The fathers of classical economics, A. Smith and D. Ricardo, repeatedly stressed in their books that risk-takers expect a reward in return, reward that they regarded as an element of natural, fair profit. Adam Smith also drew on the phenomenon of risk to demonstrate the legitimacy of entrepreneurial profit. However, none of them analysed the very phenomenon of risk in its various forms or its impact on market participants. As a result, the classical school of economics recognised risk merely as another component of normal operating costs.

Risk was initially studied by Girolamo Cardano, an Italian physician, physicist, mathematician and gambler, who wrote the first known treatise on risk in 1560, entitled Liber de ludo aleae (The Book on Games of Chance), where he attempted to establish statistical laws of probability and relied on fractions to describe probability. His work was not published until 1663, i.e. 103 years after it had been written. In the $17^{\text {th }}$ century, risk was explored by many people, including Chevalier de Méré, Blaise Pascal, Pierre de Fermat, Christiaan Huygens, John Graunt and William Petty 2 .

Nowy stownik jezyka polskiego PWN (PWN New Polish Dictionary) defines risk as a possibility or probability that something will fail; a venture the result of which is unknown, uncertain, problematic; daring to face such a danger (Nowy stownik jezyka polskiego $P W N, 2002$, p. 887). The notion of risk appears to have been derived from Arabic, where risq means fate or God's dispensation; anything that is given by God and yields profit; it has, therefore, a dimension of accidental and beneficial result (Wharton, 2009, pp. 4-5). In Persian, $\operatorname{rozi}(k)$ means fate, daily payment, and bread. In Greek, riza - like Italian ris $(i)$ co - denotes a sharp rock, a reef. Ergo, it involves dangers that should be avoided by sailors and traders. A similar meaning of "risk" is found in the Brockhaus Encyclopaedia, where this term is derived from Latin defining the verb risicare as steering clear of something, such as a reef in Greek. In English, risk means a situation causing danger or possible misfortune, while the Spanish arrisco signifies courage and danger. P.L. Bernstein argues that the word "risk" comes from the Old Italian risicare, which means "dare" (Bernstein, 1997, p. 11). In this sense, risk is a choice rather than inevitable destiny.

Risk is construed differently in the relevant literature. According to A.H. Willett, it is an objectified uncertainty regarding the occurrence of an undesirable event (Willett, 1951, p. 6), whereas F.H. Knight defines it as "a measurable uncertainty" (Knight, 1964, pp. 26-27). As claimed by A. Ehrlich, risk is the possibility of failure to obtain the desired business effects, incurring unintended losses or expenses higher than expected (Ehrlich, 1981, pp. 456-457).

A different approach to risk is represented by W.D. Rowe, who states that risk is the potential for realisation of unwanted negative consequences of an event (Rowe, 
1977, p. 24). J. Black views the essence of risk as an uncertainty as to obtain the planned result. The more likely it is to achieve results other than those planned, the greater uncertainty and risk (Black, 2008, p. 426). R. Gallati defined risk in a narrower sense as the circumstances involving exposure to adversities. In a broader meaning, he described it as conditions where deviations from the desired expected result are possible (Gallati, 2003, pp. 7-8).

The economic literature sometimes approaches risk more generally, also taking into account its positive aspect, namely the chance of gain and profit. Such a concept was supported by W. Grzybowski, who described risk as involvement of economic resources and human energy to implement projects threatened by negative deviations, i.e. failure (Grzybowski, 1976, pp. 25-33). This means that risk must also create the opportunity to increase benefits beyond the projected equilibrium or at least to achieve such an equilibrium.

A slightly different definition of risk is exemplified by Kenneth J. Arrow's works. In discussing the choice theory, he considered risk to be one of the dimensions of uncertainty and decided not to define these two concepts in detail. He frequently used both terms interchangeably (Arrow, 1979, pp. 24-25). He also defined uncertainty as the state of mind of an individual, without determining the link between such a state of mind and the real probability of random events. The other extreme was advocated by M.H. Miller and F. Modigliani, who initially seemed to equate risk with uncertainty, as did K.J. Arrow, but their subsequent considerations suggest that they interpreted the two notions as probabilistic risk (Miller, Modigliani, 1958, pp. 261-297).

N. Taleb criticised risk calculations based on sophisticated mathematical models and formulated a theory that was called the black swan theory, the name inspired by the symbol of unusual things. According to it, from the point of view of risk, it is essential to manage unpredictability or very unlikely events, and in making business decisions a major role is played by blind chance treated by N. Taleb as a primary factor behind the success of business decisions.

The related literature provides many different classifications of risk. The most general division is as follows (Janasz, 2004, p. 24):

1) risk proper that is associated with the operation of the law of large numbers and relates to catastrophic phenomena such as floods, earthquakes, etc.;

2) subjective risk that is associated with the imperfection of man who subjectively evaluates the probability of occurrence of certain events in the future;

3 ) objective risk that is a form of absolute uncertainty associated with the inability to predict the development of certain phenomena.

On the other hand, C.A. Kulp introduced into the economic literature a division of total risk of economic activity into systematic risk and specific risk. The criterion for this division is defined differently, for example as the effect, frequency of occurrence or ability to control risk (Kulp, 1928, pp. 4-7).

Systematic risk (known as basic risk) refers to the general public or groups of people, hence cannot be controlled (even partially) by an individual. Such risk is associated with the forces of nature, and also results from economic conditions in a given market and the global market. Systematic risk is exemplified by changes of the weather, inflation, unemployment. These phenomena have an impact on individuals but are beyond their control. Only the national parliament, government or central bank can try to influence its level. The sources of systematic risk are, for example, changes in interest rates, inflation, taxes.

Specific risk (individual risk) is linked to future events that can be partially controlled or anticipated. Its causes can arise as a consequence of: business management, competition, liquidity, financial and operational leverage. It should be kept in mind here that one economic event may affect the price of one asset without exerting any influence over other assets (Dziwago, 1998, p. 18).

The economic literature traditionally divides risk into pure and speculative risk. This division is a consequence of distinguishing alternatives and the criterion of the type of risk materialisation outcomes. The only possible effect of pure risk is loss. On the other hand, speculative (dynamic) risk is symmetric, and the outcome of its materialisation may be either loss or gain. 
The criterion of source location leads to differentiating between internal and external risks. Internal risk is caused by endogenous factors (e.g. employees' actions, product quality, business management system) and always has a specific character. External risk, on the contrary, is determined by exogenous factors, forces of more and less distant environment, such as: political situation, economic situation, natural environment, legislative, technological, social, demographic changes, and existing and potential competitors, suppliers and recipients.

\section{Controversies Over the Distinction Between Uncertainty and Risk}

The first researcher who became interested in the conditions of risk and uncertainty and introduced these two concepts to the economic literature in 1752 was R. Cantillon. The innovative ideas of that English economist proved apt and fertile. However, those concepts grew in importance thanks to deliberations by successive generations of economists. Thereafter, J.H. von Thünenn, a German economist and agronomist, pointed out that risk could be calculated and insured. Nevertheless, the first to outline the differences between uncertainty and risk in 1901 was A.W. Willett, who claimed that risk is objectively correlated with subjective uncertainty. He believed that risk and subjective uncertainty are interrelated. Determining the degree of risk requires knowledge of previous conditions. Perfect cognition, however, has a relative character. Defining this category, A.W. Willett stated that risk is an objectified uncertainty regarding the occurrence of an undesirable event. It depends on uncertainty rather than the degree of probability. The risk level for each individual case can be quantified or specified through direct observation or by means of statistical analysis of the results obtained from previous experiments (Willett, 1901, p. 33).

Another economist who argued that the concepts of uncertainty and risk should not be confused but should rather be seen as completely distinct categories was F.H. Knight. He claimed that risk refers to cases that could be measured and quantified, with no such possibility for uncertainty. Risk is, therefore, a mea- surable uncertainty, while uncertainty is immeasurable. Uncertainty refers to events (phenomena) of a qualitative nature. Risk refers to events actually occurring. Another feature of risk is the fact that it refers to adverse events (e.g. the risk of loss), while uncertainty is attributed to favourable outcomes (e.g. the uncertainty of profit). This means that the concept of "objective" probability may be applied to risk, whereas "subjective" probability may refer to uncertainty. Another difference lies in the knowledge of results distribution within a group of cases. From this point of view, uncertainty refers to situations or events that are absolutely exceptional. In turn, risk concerns events where results distribution can be determined a priori or on the basis of past statistical studies. Therefore, F.H. Knight assumed that risk is uncertainty that can be measured, and uncertainty is immeasurable (Knight, 1964, p. 33). Thus, risk is a state of the world, whereas uncertainty is a state of mind. In other words, the term "uncertainty" concerns cases that cannot be studied by means of probabilistic methods. Risk, on the other hand, applies to cases where such methods can be used (Lange, 1967, p. 204). C.A. Williams Jr., M.L. Smith and P.C. Young were of a similar view, claiming that risk as an objective concept is measurable, while uncertainty is treated as a subjective notion, hence cannot be measured (Williams, Smith, Young, 2002, pp. 29 and 34-35). In turn, B. Snowdon, H. Vane and P. Wynarczyk argue that risk is both measurable and insurable, whereas uncertainty does not have these characteristics. Risk characterises a situation where the probability distribution is known, quantifiable, closed and complete. In contrast, authentic uncertainty has no known probability distribution, is impossible to specify, and is open to a "potential surprise" and novelty (Snowdon, Vane and Wynarczyk, 1998, p. 396). It can thus be said that the basic characteristics that distinguish these two terms are quantifiability and insurability.

A slightly different approach to differentiating between these concepts was adopted by J. Pfeffer, an American business theorist, who claimed that risk is a combination of hazards measured by probability, while uncertainty as a psychological category is measured by the level of confidence. 
Finally, he stated that risk is a state of the world, while uncertainty is a state of mind.

In this context, Dutch social psychologist G. Hofstede's statement is interesting. Speaking about the attitude to uncertainty and risk, he said that the link between uncertainty and risk is such as that between anxiety and fear. Fear and risk are focused on something specific: an object or a person. Anxiety and uncertainty are unspecified feelings. This is a situation where anything may happen and there is no idea what it could be (Hofstede, 2000, p. 184). The sources of uncertainty include complexity, indeterminacy and discontinuity of social and economic phenomena, which consequently translates into subject-related, object-related ${ }^{3}$ and structural uncertainty. The source of risk, on the other hand, are people who make decisions consciously (Kaczmarek, 2001, pp. 22-23).

The main differences between risk and uncertainty arise from possessed information, previous practices and the impact on the quality of decisions. Relationships and differences between the two concepts are presented in Table 1.

In summary, uncertainty may be said to be a broader concept than risk, with the latter being a measurable derivative of the former. In the case of risk, the prob- ability of events is predictable and can be expressed by a mathematical formula ${ }^{4}$, with a foreseeable range of future events, whereas in the case of uncertainty, the scope of future events is not exactly known, so the probability of their occurrence cannot be determined. Thus, we talk about risk when the probabilities of their occurrence can be estimated for a number of possible situations. If the probabilities are not known and cannot be defined, then we say that the risk-taker acts under uncertainty. Both concepts differ in that the consequences of choosing a given option cannot be fully predicted, yet the information is abundant enough to determine the probability of achieving the desired result. However, what both risk and uncertainty have in common is the lack of certainty as to the consequences of the action taken. In conclusion, risk may be said to be a measurable uncertainty.

In this article, we will understand risk as the product of probability and magnitude of negative consequences arising out of an action or no action in the area of countering threats or seizing opportunities. In contrast, uncertainty will be construed as a situation where the probability of future states of affairs cannot be predicted. Thus, it cannot be measured.

Table 1. Relationships and differences between the ways of economic understanding risk and uncertainty

\begin{tabular}{|c|c|}
\hline Risk & Uncertainty \\
\hline $\begin{array}{l}\text { Part of uncertainty that business entities are } \\
\text { aware of. }\end{array}$ & $\begin{array}{l}\text { Randomness of an event resulting from unfore- } \\
\text { seen behaviours or phenomena. }\end{array}$ \\
\hline Measurable, objective, empirical. & Immeasurable, subjective, subconscious. \\
\hline $\begin{array}{l}\text { A posteriori - refers to cognition founded on } \\
\text { experience; reasoning about something through } \\
\text { induction. }\end{array}$ & $\begin{array}{l}\text { A priori - refers to pure cognition undistorted } \\
\text { by knowledge derived from other similar } \\
\text { experiences. }\end{array}$ \\
\hline $\begin{array}{l}\text { Uncertain event with a known probability of } \\
\text { occurrence. }\end{array}$ & Unpredictable or unlikely event. \\
\hline $\begin{array}{l}\text { Uncertain event the materialisation consequenc- } \\
\text { es of which can be previously estimated. }\end{array}$ & $\begin{array}{l}\text { Random event the materialisation consequenc- } \\
\text { es of which cannot be previously estimated. }\end{array}$ \\
\hline $\begin{array}{l}\text { Measurable uncertainty of achieving the objec- } \\
\text { tives set. }\end{array}$ & $\begin{array}{l}\text { Unpredictability of failure to achieve the } \\
\text { objectives set. }\end{array}$ \\
\hline Premium for taking. & No premium for acting under uncertainty. \\
\hline
\end{tabular}

Source: Dudziak and Szpakowska (2013). 


\section{Risk Measurement Methods and Evaluation Criteria for Decisions Made Under Uncertainty}

In analysing decision-making under uncertainty and risk, K.J. Arrow (1979, p. 22) distinguished three types of economic phenomena involving uncertainty:

1) phenomena that by definition involve uncertainty (e.g. games of chance and insurance);

2) phenomena that by definition do not involve uncertainty but cannot be explained in any other reasonable manner (e.g. legally guaranteed income, variable income from securities, storing surplus stock);

3) phenomena with more distant and debatable connection to uncertainty (e.g. those related with profit and the free entrepreneurship system).

The situation of uncertainty is extremely complicated from the point of view of decision-making as it involves knowledge of one's own decisions, possible states of the environment and the lack of knowledge about the probabilities of occurrence of these states. In such a situation, a decision-maker, e.g. a household or company, may decide to consume or produce based on one of four criteria:

1) The pessimistic criterion (Wald's maximin), presuming that a decision-maker assumes that whenever a decision is made, the environment generates such states that minimise the effects. The decision-maker thus chooses such an action that maximises the utility of the outcome in the worst state of the environment. Wald's criterion, therefore, takes into account the possibility of successful implementation in the least favourable circumstances. Hence, it is an extremely pessimistic approach whereby the security level is defined for each alternative and the decision maximising this level is chosen.

2) The optimistic criterion (Hurwicz's maximax), based on the assumption that a decision-maker acts opposite to the pessimistic criterion, i.e. assumes the most favourable conditions and maximises utility. Taking into consideration their own preferences, decision-makers predict the occurrence of an optimistic and pessimistic situation. Following a compromise strategy, they select either the maximax or maximin variant. In other words, Hurwicz's maximax rule presumes that a decision-maker should rank strategies on the basis of the weighted average of security and optimism levels.

3) The regret criterion (Savage's minimax) ${ }^{5}$, which proposes to measure regret as the difference between the utility of the reward actually received and the utility of the reward that could have been obtained if the state of nature that occurred had been known in advance. Hence, a decision-maker chooses the option the implementation of which involves the smallest of the maximum losses. Thus, the most secure option is chosen. This means that the decisionmaker chooses the decision that minimises the maximum relative loss based on the matrix of relative losses.

4) Laplace's equal probability criterion, also known as Bayes' rule, reduces a situation of uncertainty to that of risk, assuming that as we do not know the actual probability of occurrence of individual states of the environment, the probability is the same for all states. Under such an assumption, the procedure used is identical to that for risky situations. In other words, Laplace's law presumes that as a decision-maker is not able to determine which scenario will eventually occur, he or she may assume that all states of nature are equally probable. Laplace's indicator should then be calculated as the expected reward for each option and the decision for which the indicator is the highest should be chosen.

\section{Decision-Making Under Risk}

There are many different ways of classifying decision-making situations. According to the division based on the amount of information, we distinguish decision-making under (Luce and Raiffa, 1957):

1) certainty,

2) ignorance,

3) conflict,

4) uncertainty,

5) risk.

Decisions are made under certainty if decision-makers have complete, even perfect, knowledge, know all possible lines of their actions, and are fully aware of 
the result of choosing a particular option (alternative). In such a situation, decisionmaking does not cause much difficulty. Decision-makers need to choose that action that yields the greatest utility as a result. Under certainty, programmable decisions are taken that relate to deterministic and routine problems. It should be noted that such a situation is very rare in practice.

Decisions are made under ignorance when decision-makers may not only be unaware of all possible states of the environment but also may not know their possible actions and/or results in a particular state of the environment. Decision-makers must decide whether to obtain information that can reduce their ignorance or make a decision forthwith. In practice, this type of decision-making occurs most frequently (very often in financial markets), but it is most difficult to analyse.

In the case of decisions under conflict ${ }^{6}$ the primary task of a decision-maker is to resolve the conflict and only then to make a decision. Otherwise, reconciling these two issues is not only impossible but also may lead to painful, not only interpersonal, consequences. Decisions taken under conflict are generally characterised by considerable uncertainty caused by the inability to predict human behaviour. Decision-making under conflict is not conducive to negotiations since a consensus must be reached by two (or more) hostile parties. Another issue associated with this problem is that it is very important for the decision-maker to accept the decision already taken. For example, when a company faces problems, it often gives up the best solutions to choose such ones that other persons involved in the whole process will at least partially agree to.

Decisions are made under uncertainty when the decision-making situation can be characterised by means of a list of acceptable decisions (decision options, strategies) and states of the surrounding reality. These states have a significant impact on the outcome but when making a decision, we do not know which of them will occur and we do not have any influence over it. It is not possible for a decision-maker to determine the probability of a given state. When decisions are made under uncertainty, the consequences of considered actions generally cannot be fully predicted. Therefore, decisions taken are not programmable and focus on solving problems that are completely non-deterministic.

Decisions are made under risk when various states of the environment are possible and a decision-maker choosing from among actions is able to assess the probability of their occurrence. It can thus be said that for decisions made under risk, the effects of considered actions are uncertain. Nonetheless, this uncertainty is not complete because a decision-maker is able to estimate the probabilities of uncertain consequences. In such a situation, decisions made are partly programmable, with known probabilities of particular options. That is why, decisions under risk are often referred to as decisions made with full probabilistic information (Tyszka, 2010).

All kinds of games of chance are assumed to be the perfect model example of risky decisions. They even inspired reflections on choices made under risk. This started in 1654, when Chevalier de Méré, an avid gambler and bon vivant, trying to find the "method" for games of chance, asked his friend, Blaise Pascal, a French mathematician, physicist, philosopher and Christian apologist, for help in resolving a number of issues related to games. B. Pascal exchanged letters on that topic with another famous French mathematician, Pierre de Fermat. Soon, the exchange resulted in the concept of mathematical expectation, which was then considered to be the nature of rational choice.

B. Pascal formulated the first principle of choice under risk - the so-called expected value (EV) maximisation principle. According to this criterion, a decisionmaker should always choose the option with the largest expected value. The maximum value principle states that a decisionmaker chooses between risky operations by comparing their expected values, i.e. the weighted sum obtained by adding the values of results multiplied by their corresponding probabilities. Taking into account the expected value, the following gambles are distinguished:

- fair gambles, where $E V=0$,

- positive-expectation gambles, where $E V>0$,

- negative-expectation gambles, where $E V<0$,

The basic concepts referring to the expected value principle are value (payout) and probability of a particular con- 
sequence. The value represents expected gains or losses that may occur when choosing a given alternative. Probability, which can be calculated or estimated, means identifying the frequency of occurrence of events of interest to the decision-maker among all such events. The ways to estimate probability include expert opinions, market research, our own experience or monitoring the actions of competitors. In practice, almost no assessment of probability is either completely objective or entirely subjective.

Swiss mathematician Nicolas Bernoulli was the first to draw attention to the fact that people's assessments are not driven by uncertain results but by expected value. N. Bernoulli, presenting the St. Petersburg Paradox $^{7}$, asked the question of how much a potential participant should pay for the opportunity play a game involving successive tosses until a tail appears (when it does, the game ends). A game participant receives payouts according to the following principle: if the game ends on toss $(n+1)$, the participant wins $2^{\mathrm{n}}$ ducats. It is easy to calculate that the expected value of this game is infinite; therefore, in accordance with the principle proposed by N. Pascal, a potential participant should be willing to pay an infinite amount for participation. However, it is known that no player will do so and no one will accuse him or her of acting irrationally. Therefore, Daniel Bernoulli, Nicolas' cousin, asserted that expected value maximisation could not be a rational choice criterion under risk. In his deliberations, he concluded that people do not follow the expected value maximisation principle because they are driven not by an objective but a subjective measure of value, i.e. utility. D. Bernoulli defined utility as an increasing function of wealth characterised by diminishing marginal sensitivity. This means that the utility of subsequent wealth growth is lesser and lesser. Given that, D. Bernoulli replaced the objective value of the game outcomes in the formula of expected value with their subjective utility. He proposed the expected utility maximisation principle, which became the basis for models of rational choices under risk. In 1738, he put forward the hypothesis stating that in the assessment of game payouts, what is important is the value of expected utility of payouts rather than their expected value ${ }^{8}$. A function must be then created that attributes utility to individual outcomes according to the utility function that is known in the conditions of full probabilistic information. The expected utility hypothesis regarding the way in which individuals behave under risk was applied as late as in 1944 by John von Neumann and Oskar Morgenstern and became a formal model of decision-making under risk with well-defined postulates of rational behaviour. Their theorem assumed that a rational decision-maker acts in accordance with the expected utility maximisation principle, known as Bernoulli's principle (Neumann, Morgenstern, 1944). J. von Neumann and O. Morgenstern formulated preference axioms that allowed them to show the existence of utility function (Zalega, 2012, p. 88).

In practice, the utility function is not known. For simplicity, the utility function is constructed on a set reduced to the consequences that are devoid of risks. If the consequences are expressed in monetary units, their described utility function is called the utility function of wealth. Further, the lottery utility is assumed to be the expected utility value of outcomes that are components of the lottery.

According to von Neumann-Morgenstern theorem, such a decision is chosen that brings the maximum expected value. This choice will vary depending on the shape of the utility curve.

Three basic relationships exist between the form of the utility function and the attitude of the decision-maker to risk:

1. Decision-maker (risk-avoider) with a concave utility function is risk averse.

2. Decision-maker (risk-taker, gambler) with a convex utility function is a riskseeker.

3. Decision-maker with a linear utility function is risk neutral.

Rational decision-makers seek to maximise the expected value, namely direct their actions towards the biggest gains. Given that the scale of their preferences is based on subjective assessments, they have their specific utility functions. Such functions allow them to fully rank their preferences within a set of alternative decisions. This ranking should be asymmetric and transitive. Asymmetry involves an individual preferring the first option to the second one who cannot simultaneously prefer the latter to the former. Transitive ranking 
means that the decision-maker favours the first option over the second one and the second over the third and simultaneously prefers the first option to the third one. Yet preference ranking is not always asymmetric and transitive. This is because the rationality of decision-makers is limited, posing a problem in the application of normative decision theories.

The expected utility function, in view of its simple design, has the following characteristics:

- the utility scale is clearly determined with precisely defined zero point and measurement unit,

- its linearity is closely linked with the independence axiom,

- it is monotonic because of payouts; for a given lottery, an increased payout means an increased utility of the lottery,

- it satisfies the stochastic dominance condition. ${ }^{9}$

The expected utility hypothesis has been criticised on numerous occasions because investors actually do not make decisions as described therein. A weakness of the basic assumption coined by Bernoulli, stating that the measure of satisfaction is utility that is dependent on the current wealth, lies in disregarding past states. According to this assumption, for two investors having PLN 5 million each, the utility of their wealth should be identical. Is it really true, however, if one of them owned assets worth 10 million the day before and another had wealth of 1 million (Kahneman, 2012, p. 365)?

Summing up the presented models that describe risky choices, it may be noted that:

- what differentiates them is the objective versus subjective treatment of the values of outcomes of options,

- what they have in common is the assumption of an objective probability distribution over the set of possible outcomes of options.

Both the expected value (EV) maximisation principle and the expected utility (EU) maximisation principle presume that the decision-maker knows this distribution, which determines his or her choices.

Given that every decision-maker evaluates risk differently, the research by J.L. Savage led ultimately to the establishment of the subjective expected utility principle in $1954^{10}$. This principle takes into account two variables: probability of subjectively anticipated outcomes and their utility. J.L. Savage showed that by analogy with the postulates put forward by von Neumann and Morgenstern, it is possible to formulate a set of postulates the fulfilment of which leads to an individual's behaviour maximising subjective expected utility. In addition to subjective evaluation of consequences of possible choices, the principle of subjective expected utility also allows subjective treatment of probabilities associated with these consequences. It is, therefore, a version of the maximisation principle that is even more adapted to real situations. It recommends the choice of such an action that allows the best combination of what is probable and what is subjectively valuable, i.e. what is possible to achieve and what a decision-maker considers to be beneficial and valuable for him or her. The optimum behaviour in the sense of subjective expected utility involves such actions that maximise the average utility value in view of the subjective probability distribution ${ }^{11}$.

The related literature presents many other theories and models that strive to replace, modify or develop the expected utility hypothesis. Examples include the revealed preference theory of temptation and self-control and the dual theory of choice under risk (Yaari, 1987).

One of the first economists who conducted an experiment to demonstrate that the preferences of gamblers develop differently from what the expected utility hypothesis assumes was French economist Maurice Allais. In 1952, he presented an experiment on the economics of risk, known as the Allais paradox, at a world meeting of economists in Paris. He asked the participants to make a choice between two lotteries. As expected by M. Allais, competent and intelligent attendees did not notice that their preferences violated the expected utility hypothesis until he told them about that at the end of the meeting. M. Allais probably believed that the participants would be persuaded to abandon the theory, which he quite contemptuously called the "American school", and shift to the alternative logic of choices developed by Allais himself. However, the economists, who were not interested in the decision theory, mostly ignored the Allais paradox. ${ }^{12}$. As is often the case when a commonly accepted theory that leads to 
useful results is challenged, they considered the whole issue an irrelevant anomaly and still employed the expected value hypothesis as if nothing had happened. Nevertheless, decision-making theorists treated the criticism by Allias very seriously (Babula, Blajer-Gołębiewska, 2009).

The experiment proposed by M. Allais assumes that one of the lotteries is a lottery with a certain outcome. Part of the research into Allais paradox involved the so-called certainty effect ${ }^{13}$. Such research was conducted, inter alia, by Daniel Kahneman and Amos Tversky, who presented the results of their experiments in the article Prospect Theory: An Analysis of Decision under Risk published in 1979. In that study, which is considered to be critical of the expected utility hypothesis, those authors, based on the results of their experiments, found that the choice between risky lotteries leads to choosing the lottery with certain wins, and such behaviour is not consistent with the fundamentals of the expected utility hypothesis (Kahneman, Tversky, 1979). The expected utility hypothesis assumes that utilities of outcomes are weighted by probabilities of their occurrence. D. Kahneman and A. Tversky noted that people generally overestimate the weights for a certain win compared to the weights for probable outcomes. This tendency is called the Allais certainty effect and causes risk aversion to appear in choices where we have lotteries with a certain win, while the risk-taker attitude appears in choices threatened by losses.

In the already mentioned prospect theory, D. Kahneman and A. Tversky adopted the assumption that utility, which they referred to as value or psychological value, should be analysed not in view of the current wealth of an investor but in the context of a change in wealth (profit and loss) against the investor's subjective point of reference (Zalega, 2012b, p. 40). Based on numerous studies, they determined the shape of the value function. It is concave above the reference point and convex below this point. This means that utility of both consecutive income units and consecutive loss units decreases (consecutive gains bring lesser satisfaction, and consecutive losses are less painful). This phenomenon results in risk aversion and risk seeking as far as gains and losses, respectively, are concerned (Szyszka, 2009, p. 57). The shape of the value function (it is steeper for losses than for profits) also shows that an investor feels more intense dissatisfaction with a loss of certain absolute value than satisfaction with a gain of the same value.

The second part of the prospect theory defines the probability weighting function. The function shape and scope of variables, different from the linear probability function calculated mathematically, were specified by D. Kahneman and A. Tversky on the basis of numerous psychological experiments. This function "is characterised by decreasing sensitivity to changes in the probabilities as the distance from the reference point increases (for $\mathrm{p}=0$, impossibility or $p=1$, certainty). The consequence of decreasing sensitivity is a concave function in the case of probabilities close to 0 and a convex function for probabilities close 1 . According to the actual assessment of the situation (...) by individuals, the function overvalues low probabilities and undervalues high and medium probabilities. Its shape is, moreover, characteristically asymmetric since the convex section is about twice bigger than the concave one. It is also worth noting that the function is not clearly specified around certainty and impossibility. Highly improbable events are either ignored or overestimated, and the difference between high probability and certainly is either neglected or overly exaggerated" (Czerwonka, Gorlewski, 2012, pp. 59-60). Later, D. Kahneman and A. Tversky developed the prospect theory so that it could be used also in conditions of uncertainty (the cumulative prospect theory) (Tversky and Kahneman, 1992; Wakker, 2010). However, as D. Kahneman himself argues, the prospect theory does not explain all investor behaviours, e.g. it is inadequate for disappointment and regret (Quiggin, 1982). In the cumulative prospect theory, the key implication is the so-called fourfold pattern of risk attitude (Wakker, 2010, pp. 342-369).

It proves that decision-makers:

1. avoid risk for moderately or highly probable gains,

2. seek risk for moderate or highly probable losses,

3. seek risk for unlikely gains,

4. avoid risk for unlikely losses.

The prospect theory has gained wide recognition and is broadly used to explain the choices made. For example, referring to it, 
H.R. Thaler developed the principles of the so-called mental accounting among buyers, including (Thaler, 1999, pp. 183-206):

1. The principle of separation of gains higher satisfaction is felt with several smaller gains than with one gain.

2. The principle of combining losses lesser dissatisfaction with one bigger loss than with several smaller ones.

3. The principle of combining smaller losses with greater gains - more satisfaction with one aggregate gain when a smaller loss is combined with a greater gain than with separate gains.

4. The principle of separating smaller gains from greater losses - lesser dissatisfaction when smaller gains are separated from greater losses than when these are summed.

These assumptions allow for concluding that the prospect theory refers to the actual decision-making under risk most realistically now.

The latest idea of utility is being developed by D. Kahneman and his colleagues as the so-called experimental utility theory. It refers to long abandoned understanding of utility as something that is directly observable and measurable. Even J. Bentham understood this concept in this way, although later, in the modern decision theory, utility was construed only as something that we conclude about from an individual's choices. D. Kahneman, however, shows that the concept of experimental utility explains many seemingly paradoxical human behaviours.

\section{Conclusion}

People's choices are influenced by different determinants. A key role in decision-making is played by uncertainty and risk. Decisions are made under uncertainty when the decision-making situation can be characterised by means of a list of acceptable decisions (decision options, strategies) and states of the surrounding reality. These states have a significant impact on the outcome but when making a decision, we do not know which of them will occur and we do not have any influence over it (Pazek, Rozman 2009, pp. 45-50). Risk, on the other hand, is a function of uncertainty, and this relationship is directly proportional: the greater the uncertainty, the greater the risk and vice versa - when undefined and uncertain factors decrease, risk also diminishes.

In contrast to decision-making under risk, decision-making under uncertainty means that it is not possible for a decisionmaker to determine the probability of a given state. F.H. Knight first suggested that risk and uncertainty so construed should be used in economics; however, these two categories were only formally introduced to the economic theory by von Neumann and Morgenstern. In response to the utility hypothesis and its axioms, M. Allais proposed an experiment that challenged the prediction of the expected utility hypothesis and was to show the choices inconsistent with the axiom of independence, thus excluding non-linearity of the expected utility function. Afterwards, L.J. Savage expanded the assumptions of expected utility to include subjective probability as opposed to objective probability. As his concept of subjective expected utility is difficult to apply in practice, D. Kahneman and A. Tversky proposed the prospect theory, which allows an adequate description of the actual choices made by people who use many heuristics when making decisions under risk. The prospect theory finds its continuation in the experimental utility concept developed by D. Kahneman that refers to the measurability of utility.

The incorporation of risk and uncertainty in the economic theory not only brought it closer to the reality of economic life but also enriched and dynamised the development of economic sciences. The effectiveness of solutions to the problems of risk and uncertainty, present in the economic practice, undoubtedly shows the progress of civilization and affects the growth of prosperity of modern societies.

\section{Footnotes}

1 The interpretation of risk varies from one scientific field to another; therefore, it is not possible to formulate a single universal definition thereof.

2 G. Cardano, B. Pascal and P. Fermat laid the foundations of the probability theory, trying to solve some problems associated with games of chance. Ch. Huygens was among the pioneers of the dice game theory. His theory was then published in 1657 in the book De ludo aleae regarded as one of the first works on the probability theory. 
3 Subject-related uncertainty is a result of theoretical and methodological competences of the cognising man (subject). Their level directly determines how effectively the object cognised is identified. On the other hand, object-related uncertainty involves the nature of the object cognised the contents, including characteristics, of which will never be fully known.

4 Since risk can be described by means of probability distribution, risk quantification is often associated with a probabilistic approach and probabilistic methods used to assess the risk of economic activity pursued by economic entities (businesses, households).

5 In 1954, mathematician Leonard Savage introduced the concept of subjective probability into the theory of maximum utility, thereby making it possible to use this theory also under conditions of uncertainty. A subjective probability assessment of a particular event depends on an investor's personality traits, knowledge and experience. A rational decisionmaker using the value of subjective probability maximises subjective expected utility defined as the sum of the products of utility of certain events and subjective probabilities of their occurrence.

6 The process of decision-making under conflict can be described by means of a strategic game where investors seek to achieve the dominant strategy equilibrium or the Nash equilibrium.

7 Nicolas Bernoulli, in his correspondence, especially with French mathematician P. de Montmort, was the first to describe the problem of the St. Petersburg paradox, although the name and the solution to this problem were established by his cousin, Daniel Bernoulli. The proposed solution was to introduce the idea of moral wealth, which unnecessarily made calculation results highly subjective.

8 Daniel Bernoulli denied the previous view that the value of each additional monetary unit was the same for the beneficiary, regardless of the value of wealth already owned. On that basis, he formulated the claim that a rational individual, when taking decisions under risk, tends to maximise expected utility understood as the sum of the products of utility of certain events and the probabilities of their occurrence. The concept of expected utility includes a subjective element, since a particular event may have a different expected utility for different investors. One factor affecting the subjectivity of expected utility maximisation is the attitude towards risk.

9 Stochastic dominance indicates that the utiity of a lottery should grow when the probability distribution of the lottery changes in such a manner that a higher payout becomes more likely, thus reducing the likelihood of a lower payout. This means that from among two lotteries with the same payouts, the dominating lottery is that which offers higher probability of higher payouts. More in: L.J. Savage, The Foundations of Statistics, Dover Publications, New York 1972, p. 114 et seqq.

10 The foundations of this principle can be found in the works by F.P. Ramsey from 1929 and B. de Finetti from 1937, whose achievements were synthesised - and compared with the views of J. von Neumann and O. Morgenstern - by J.L. Savage in: The Foundations of Statistics, John Wiley \& Sons, Inc., New York 1954 - as cited in G. Maciejewski, Ryzyko w decyzjach nabywczych konsumentów, Wydawnictwo UE, Katowice 2010, p. 69.

11 If the decision-maker knows objective probability of certain states of affairs, the best action is one that maximises average utility $\mathrm{n}$ view of the objective probability distribution.

12 The experiment results also depend on the group of respondents. Allais paradox can be analysed both in a group of people who know to a certain extent the principles of the decisionmaking theory and in a group of people who have nothing to do with this field. Many experiments were carried out simultaneously in two or more groups, yet the differences between the results obtained for a particular experiment in the various groups were not significant in any case. More in: P.R. Blavatsky, Reverse Common Ratio Effect. Journal of Risk Uncertain, 40/2010.

13 On the basis of his experiments, M. Allais noted that risky prospects become more attractive if the probabilities of winning in two lotteries are multiplied by the same common factor. In this way, we get lotteries with the common ratio effect. This effect is another example of the violation of the expected utility hypothesis. Here the substitution principle is violated. More in: M.H. Birnbaum and U. Schmidt, Allais Paradoxes can be Reversed by Presenting Choices in Canonical Split Form. Kiel Working Paper, $1615 / 2010$.

\section{References}

Arrow, K.J. (1979). Eseje z teorii ryzyka. Warszawa: PWN. Reprint of the original article: Alternative Approaches to the Theory of Choice in Risk-Taking Situations, Econometrica 1951, 19(4), 404-437.

Babula, E. and Blajer-Gołębiewska, A. (2009). Interpretacja paradoksu Allaisa za pomoca modelu konfiguralnie ważonej użyteczności. In: D. Kopycińska (ed.), Wybory konsumentów $i$ przedsiębiorstw $w$ teorii $i$ praktyce. Szczecin: Wydawnictwo US.

Bernstein, P.L. (1997). Przeciw bogom. Niezwykte dzieje ryzyka. Warszawa: WIG-Press.

Birnbaum, M.H. and Schmidt, U. (2010). Allais Paradoxes can be Reversed by Presenting Choices 
in Canonical Split Form. Kiel Working Paper, No. 1615.

Black, J. (2008). Stownik ekonomii. Warszawa: Wydawnictwo Naukowe PWN.

Blavatsky, P.R. (2010). Reverse Common Ratio Effect. Journal of Risk Uncertain, 40.

Czerwonka, M. and Gorlewski, B. (2012). Finanse behawioralne. Zachowania inwestorów $i$ rynku. Warszawa: Oficyna Wydawnicza SGH.

Ehrlich, A. (1981). Ryzyko gospodarcze. In: Encyklopedia organizacji i zarzadzania. Warszawa: PWE.

Dudziak, M. and Szpakowska, E. (2013). Zarzadzanie ryzykiem i niepewność $w$ działalności gospodarczej. Podejmowanie decyzji biznesowych. Retrieved from: http://zif.wzr.pl/pim/2013_1_1_9.pdf (02.03.2015).

Dziawgo, D. (1998). Credit-rating. Ryzyko i obligacje na międzynarodowym rynku finansowym. Warszawa: PWN.

Gallati, R. (2003). Risk Management and Capital Adequacy. New York: McGraw-Hill.

Heijden van der, K. (2000). Planowanie scenariuszowe $w$ zarządzaniu strategicznym. Kraków: Oficyna Ekonomiczna.

Heilpern, S. (2001). Podejmowanie decyzji $w$ warunkach ryzyka i niepewności. Wrocław: Wydawnictwo AE.

Hofstede, G. (2000). Kultura $i$ organizacja. Warszawa: PWE.

Grzybowski, W. (1976). Ryzyko w procesie podejmowania decyzji. Studium teoretyczno-badawcze. Lublin: UMCS.

Grzybowski W. (1995). Przedsiębiorczość, niepewność, zysk. Lublin: UMCS.

Janasz, K. (2004). Ryzyko kredytowe w systemie bankowym. Szczecin: Wyd. Naukowe Uniwersytetu Szczecińskiego.

Kaczmarek, K.T. (2001). Zarzadzanie ryzykiem w przedsiębiorstwie eksportującym. Gdańsk: ODiDK.

Kahneman, D. and Tversky, A. (1979). Prospect Theory: An Analysis of Decision under Risk. Econometrica, 47(2).

Kahneman, D. (2012). Pułapki myślenia. O myśleniu szybkim $i$ wolnym. Poznań: Media Rodzina.

Knight, F.H. (1964). Risk, Uncertainty and Profit. Reprints of Economic Classics. New York: Augustus M. Kelley.

Kulp, C.A. (1928). Casualty Insurance. New York: Ronald Press.

Lange, O. (1967). Optymalne decyzje. Zasady programowania, $2^{\text {nd }}$ revised edition. Warszawa: PWN.
Luce, R.D. and Raiffa, H. (1957). Games and Decisions: Introduction and Critical Survey. New York: John Wiley \& Sons.

Maciejewski, G. (2010). Ryzyko w decyzjach nabywczych konsumentów. Katowice: Wydawnictwo UE

Miller, M.H. and Modigliani, F. (1958). The Cost of Capital and the Theory of Investment. American Economic Review, 48

Neumann, J. and Morgenstern, O. (1944). Theory of Games and Economic Behavior. Princeton: Princeton University Press.

Neumann von, J., Morgenstern, O. and Savage, J.L. (1954). The Foundations of Statistics. New York: John Wiley \& Sons, Inc.

Nowy stownik języka polskiego PWN (2002). Warszawa: Wydawnictwo Naukowe PWN

Praktyczny stownik wspótczesnej polszczyzny (2002) Vol. 23. Poznań: Wydawnictwo KURPISZ.

Pazek, K. and Rozman, C. (2009). Decision Making under Conditions of Uncertainty in Agriculture: A Case Study of Oil Crops. Poljoprivreda (Osijek), 15(1).

Rowe, W.D. (1977). An Anatomy of Risk. New YorkLondon: John Wiley \& Sons.

Savage, L.J. (1972). The Foundations of Statistics. New York: Dover Publications.

Snowdon, B., Vane, H. and Wynarczyk, P. (1998) Wspótczesne nurty teorii makroekonomii. Warszawa: Wydawnictwo Naukowe PWN.

Szyszka, A. (2009). Finanse behawioralne. Nowe podejście do inwestowania na rynku kapitatowym. Poznań: Wydawnictwo UE w Poznaniu.

Thaler, R.H. (1999). Mental accounting matters. Journal of Behavioral Decision Making, 12.

Tversky, A. and Kahneman, D. (1992). Advances in prospect theory: cumulative representations of uncertainty. Journal of Risk and Uncertainty, 5.

Tyszka, T. (2010). Decyzje. Perspektywa psychologiczna i ekonomiczna. Warszawa: Wydawnictwo Scholar.

Quiggin, J. (1982). A theory of anticipated utility. Journal of Economic Behaviour and Organization, 3.

Wakker, P. (2010). Prospect Theory for Risk and Ambiguity. Cambridge: Cambridge University Press.

Wharton, F. (2009). Risk Management: Basic Concept and General Principles. In: J. Ansell and F. Wharton (eds.), Risk, Analysis, Assessment and Management, No. 1-14. Chichester: John Wiley\& Sons, Inc.

Willett, A.H. (1951). The Economic Theory of Risk Insurance. Philadelphia. 
Willett, A.W. (1901). The Economic Theory of Risk and Insurance. Studies in History, Economics and Public Law, XIV(2). New York: The Columbia University Press.

Williams, C.A. Jr., Smith, M.L. and Young, P.C (2002). Zarzadzanie ryzykiem a ubezpieczenia. Warszawa: Wydawnictwo Naukowe PWN.

Wiśniewski, R. (2007). Wielowymiarowe prognozowanie wartości nieruchomości. Rozprawy i monogra fie. Olsztyn: Wydawnictwo UWM.
Zalega, T. (2012a). Rationality and Methods of Research Into Consumer Market Behaviour. Equilibrium, 7(4).

Zalega, T. (2012b). Konsumpcja. Determinanty, teorie, modele. Warszawa: PWE.

Yaari, M.E. (1987). The dual theory of choice under risk. Econometrica, 55. 